\title{
A New Genus and New Combinations in Australian Villarsia (Menyanthaceae)
}

\author{
Nicholas P. Tippery and Donald H. Les \\ Department of Ecology and Evolutionary Biology, University of Connecticut, Storrs, \\ Connecticut 06269, U.S.A. nicholas.tippery@uconn.edu
}

Abstract. Menyanthaceae species in Australia formerly belonging to the genus Villarsia Ventenat, which morphological and molecular data have shown to be paraphyletic, are provided with new combinations in Liparophyllum Hooker f. and the novel genus Ornduffia Tippery \& Les: L. capitatum (Nees ex Lehmann) Tippery \& Les; L. congestiflorum (F. Mueller) Tippery \& Les, lectotypified here; $L$. exaltatum (Solander ex Sims) Tippery \& Les; $L$. exiguum (F. Mueller) Tippery \& Les; L. lasiospermum (F. Mueller) Tippery \& Les, lectotypified here; $L$. latifolium (Bentham) Tippery \& Les; L. violifolium (F. Mueller) Tippery \& Les, lectotypified here; $O$. albiflora (F. Mueller) Tippery \& Les, lectotypified here; O. calthifolia (F. Mueller) Tippery \& Les, lectotypified here; $O$. marchantii (Ornduff) Tippery \& Les; $O$. parnassifolia (Labillardière) Tippery \& Les; $O$. reniformis (R. Brown) Tippery \& Les; O. submersa (Aston) Tippery \& Les; and O. umbricola (Aston) Tippery \& Les.

Key words: Australia, Liparophyllum, Menyanthaceae, Ornduffia, Villarsia.

Menyanthaceae are a morphologically diverse family of aquatic and wetland plants in the order Asterales, consisting of 60 to 70 species that are distributed worldwide (Tippery et al., 2008). Two of the five genera, Menyanthes L. and Nephrophyllidium Gilg (= Fauria Franchet), are monotypic and restricted to the Northern Hemisphere. Liparophyllum Hooker f. (also monotypic) and Villarsia Ventenat (18 species) are found only in the Southern Hemisphere, and Nymphoides Séguier (40 to 50 species) is cosmopolitan in distribution.

Tournefort (1700) had recognized two genera (Menyanthes and Nymphoides) that Linnaeus (1753) combined under Menyanthes to include the emergent wetland species $M$. trifoliata L. and two floatingleaved species that currently are circumscribed within Nymphoides: $N$. indica (L.) Kuntze and N. peltata (S. G. Gmelin) Kuntze. Séguier (1754) validly published Nymphoides subsequently; however, the later synonym Limnanthemum S. G. Gmelin (1769) remained the accepted genus name for over 100 years (Grisebach,
1845; Mueller, 1875; Bentham \& Hooker, 1876). Ventenat (1803) later segregated another genus, Villarsia, to accommodate the distinct South African species V. capensis (Houttuyn) Merrill.

Over the next century, many species were transferred between Limnanthemum and Villarsia, particularly in Australia, where taxa with either floatingleaved or emergent habit occur. Menyanthaceae species in Australia initially were designated under Villarsia (Brown, 1810; Don, 1837; Endlicher et al., 1837; Lehmann, 1845), although some were included under Menyanthes (Sims, 1807, 1810) or the gentianaceous genus Swertia L. (Labillardière, 1804-1805). In a comprehensive treatment of Menyanthaceae, Grisebach (1845) listed species of both Limnanthemum and Villarsia in Australia and provided morphological characters to distinguish the genera, including epipetalous glands, capsule dehiscence, floating leaves, and inflorescence architecture. However, Grisebach recognized only two species of Menyanthaceae in Australia, L. geminatum (R. Brown) Grisebach ( = Nymphoides geminata (R. Brown) Kuntze) and V. parnassifolia (Labillardière) R. Brown. Many additional Australian species were designated subsequently by Mueller, under both Limnanthemum (Mueller, 1854, 1858) and Villarsia (Mueller, 1860, 1865,1868 ). After noting that few characters could distinguish the genera, Mueller eventually transferred every menyanthaceous species in Australia to Limnanthemum (Mueller, 1875), including Liparophyllum gunnii Hooker f., an anomalous species for which Hooker (1847) had established a separate genus.

Other authors, however, maintained the independence of Liparophyllum and established the boundary between Limnanthemum and Villarsia out of which current generic circumscriptions developed (Bentham \& Mueller, 1869; Bentham \& Hooker, 1876). The few characters that were used to distinguish between Limnanthemum and Villarsia included capsule dehiscence and inflorescence morphology, and Liparophyllum was differentiated by linear leaves and a lack of carpellary glands. Later, Kuntze (1891) further codified the assignment of species to genera when he transferred nearly all currently recognized species 
in Australia to either Nymphoides or Renealmia Houttuyn (a Villarsia synonym and later homonym of Renealmia L. f.). Recent authors have maintained the separation of Nymphoides and Villarsia on morphological grounds that include vegetative habit and inflorescence architecture, and have supported the independence of Liparophyllum, which is unique among Menyanthaceae in having solitary flowers and linear leaves (Aston, 1973; Chuang \& Ornduff, 1992; Cook, 1996).

Divisions among Menyanthaceae genera have been upheld in part because of their relatively discrete geographic ranges. Although Nymphoides species are found worldwide and Villarsia are relatively abundant in the Southern Hemisphere, there are few areas where both genera co-occur. Species of Nymphoides are absent from southwestern Australia, where over half of Villarsia species are endemic (Aston, 1973). In addition, Menyanthes and Nephrophyllidium are restricted to the Northern Hemisphere, which precludes any overlap in range with the Southern Hemisphere genera Liparophyllum and Villarsia (Cook, 1996).

Despite the general geographic and morphological distinctness of Menyanthaceae genera, several species of different genera are remarkably similar in their floral and seed morphology, which often have been considered as diagnostic (Grisebach, 1845; Aston, 1969; Chuang \& Ornduff, 1992). Flowers in Menyanthaceae are yellow or white (rarely tinged with purple) and have either a dense covering of hair, e.g., Menyanthes trifoliata, Nymphoides indica, Villarsia submersa Aston, or lateral petal wings, e.g., Nephrophyllidium crista-galli (Menzies ex Hooker) Gilg, Nymphoides cristata (Roxburgh) Kuntze, Villarsia capensis (Tippery et al., 2008). Large seeds with smooth, elongate epidermal cells distinguish Menyanthes and Nephrophyllidium from the other genera, which have smooth to tuberculate seed surfaces that may be ornamented with trichomes, e.g., Nymphoides peltata, Villarsia exaltata (Solander ex Sims) G. Don, or a nutritive caruncle, e.g., Nymphoides subacuta Aston, Villarsia latifolia Bentham (Chuang \& Ornduff, 1992). Although the distinctness of Menyanthes and Nephrophyllidium from the remainder of Menyanthaceae has been confirmed repeatedly (e.g., Nilsson, 1973; Chuang \& Ornduff, 1992), morphological boundaries among the other genera have been obscured by a number of overlapping character states.

Phylogenetic analyses of the Asterales, conducted using both morphological and molecular data, have consistently resolved Menyanthaceae as monophyletic, within which Menyanthes and Nephrophyllidium are the sister clade to the remainder of the family (Olmstead et al., 2000; Soltis et al., 2000; Lundberg \&
Bremer, 2003). An analysis of Menyanthaceae taxa using only morphological data (including pollen, seed, and flavonoid data) resolved the floating-leaved genus Nymphoides as monophyletic, except for N. exigua (F. Mueller) Kuntze, which lacks floating leaves (Tippery et al., 2008). In the same study, Villarsia resolved as a paraphyletic grade toward Nymphoides, and Liparophyllum was unresolved as either the sister taxon of Nymphoides or a lineage within the Villarsia grade. Phylogenetic analysis of morphological characters thus indicated that although Nymphoides is monophyletic, Villarsia does not comprise a morphologically coherent group (Tippery et al., 2008).

We have conducted an updated phylogenetic analysis of combined nucleotide (nuclear ribosomal ITS [nrITS], rbcL, matK, and trnK introns) and structural (encoded matK/trnK indels and nrITS secondary structure) molecular data, using the methods outlined in Tippery and Les (2008) and Tippery et al. (2008). In addition to previously reported sequences (Tippery et al., 2008), we obtained new molecular data for one Villarsia specimen from South Africa: V. goldblattiana Ornduff (Rebelo 2008113001, NBG), and two specimens from Western Australia: V. submersa (Hort \& Crawford 1845, PERTH) and V. violifolia F. Mueller (Ornduff 9342, UC; GenBank accession numbers EU342366EU342370, FJ546980-FJ546982). The resulting phylogeny (Fig. 1) produced a congruent topology but showed better-resolved interspecific relationships than the tree generated strictly from morphological data (Tippery et al., 2008). Nymphoides was strongly supported as monophyletic, whereas Villarsia resolved as three separate clades, one of which also contained Liparophyllum (Fig. 1). The two larger Villarsia clades consisted entirely of Australian taxa, and the other clade contained only the three South African species. Each of the Australian clades included taxa from both the eastern and western floristic regions of that continent (Takhtajan, 1986). The phylogeny depicted here (Fig. 1) represents a complete sampling of Villarsia species worldwide. It should be noted that separate analyses have resolved another species, $V$. cambodiana Hance from Southeast Asia, within Nymphoides, where we recommend its transfer (Tippery et al., 2010).

Although the clades of Villarsia that were resolved in the combined data analysis have never been suggested on the basis of morphology alone, several morphological characters nonetheless support them as separate, internally cohesive groups. Species in the clade that includes the anomalous, floating-leaved species V. submersa are united by their remarkably similar seeds that are ellipsoid with a subterminal hilum (Chuang \& Ornduff, 1992). Seeds of most 


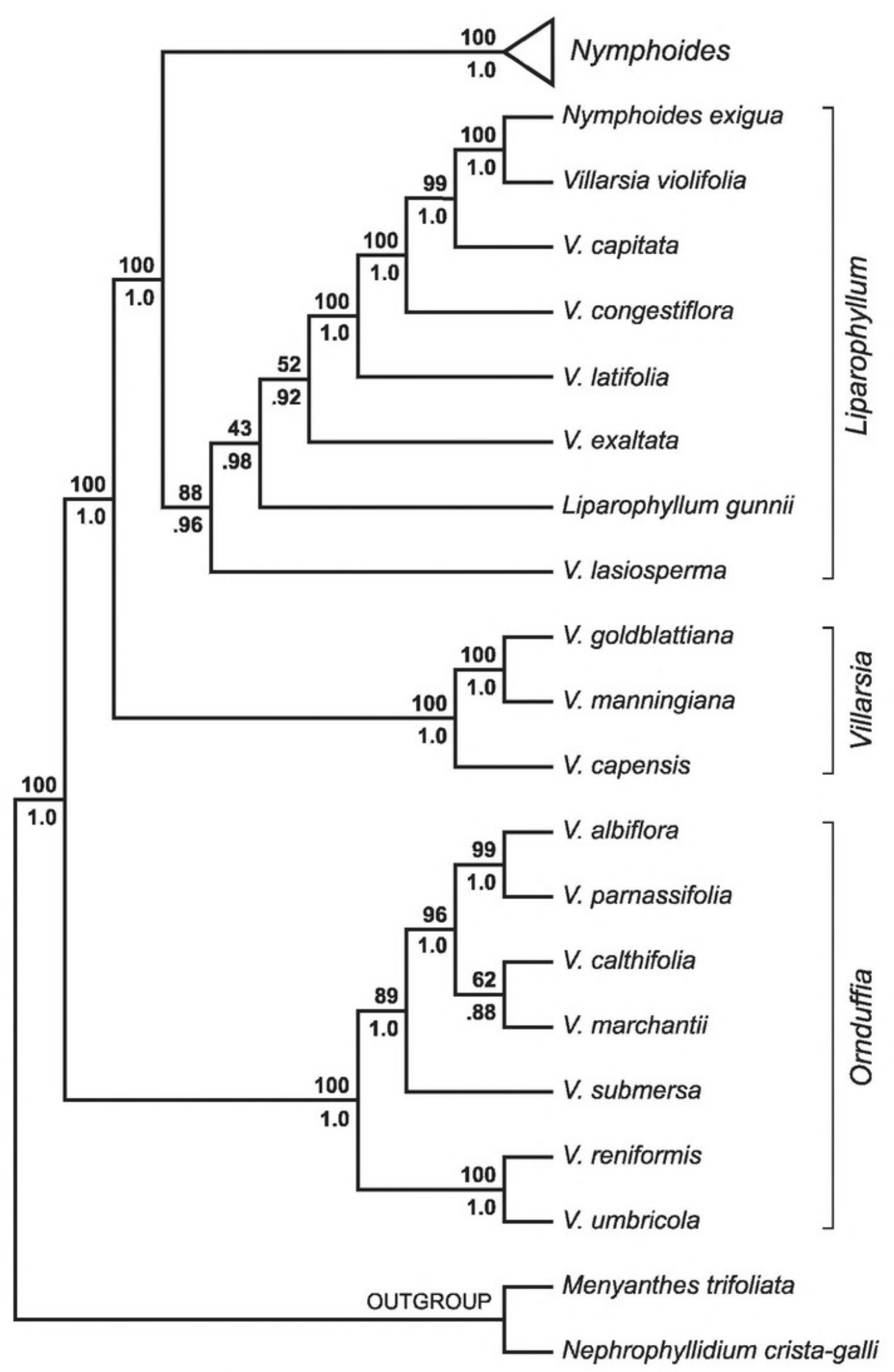

Figure 1. Phylogenetic relationships in Menyanthaceae, reconstructed using molecular data (nrITS, $m a t K, r b c L, t r n K$ introns, and nrITS secondary structure), with analyses as described by Tippery and Les (2008) and Tippery et al. (2008). Topology represents the single most-parsimonious tree; nodal values indicate parsimony bootstrap and Bayesian posterior probability support, above and below each branch, respectively. Names shown represent previously circumscribed Villarsia taxa. Revised generic circumscriptions proposed in this paper are depicted at right. 
species in the clade are smooth, although some taxa (e.g., V. albiflora F. Mueller, V. calthifolia F. Mueller) have seeds that are densely covered with acuminate trichomes. In addition, species in the clade all have substantially more ovules per placenta than other Villarsia species (Tippery et al., 2008). The South African species, which form a second clade, are characterized by the most deeply fimbriate petal margins and the fewest seeds per capsule of any Villarsia (Ornduff, 2001; Tippery et al., 2008).

The third clade resolved by the combined data analysis is quite heterogeneous taxonomically and consists of species with varied growth habit, inflorescence architecture, and seed morphology (i.e., Liparophyllum gunnii, Nymphoides exigua, several Villarsia species). Nonetheless, subsets of the taxa within this clade share a number of distinctive traits that are found nowhere else in Menyanthaceae. Among the traits are inflorescences that are few flowered ( $L$. gunnii, N. exigua, V. violifolia) or congested ( $V$. capitata Nees ex Lehmann, $V$. congestiflora F. Mueller) and various distinguishing seed features that include sparse trichomes ( $V$. exaltata, $V$. lasiosperma $\mathrm{F}$. Mueller), a smooth testa with indistinct epidermal cells ( $N$. exigua, V. capitata, V. latifolia, V. violifolia), or a nutritive caruncle ( $V$. congestiflora, $V$. exaltata, V. latifolia, V. violifolia). None of these features occurs in the other Villarsia clades (Aston, 1969; Chuang \& Ornduff, 1992; Tippery et al., 2008). Furthermore, all taxa in this otherwise diverse clade are distinct from other Villarsia in having between five and 10 ovules per placenta (Tippery et al., 2008).

Analyses of molecular data clearly indicate that Villarsia is paraphyletic as currently circumscribed (Fig. 1; Tippery et al., 2008). Consequently, in order to recognize groups that are meaningful phylogenetically, it will be necessary to revise the current taxonomy to reflect monophyletic genera. This objective can be achieved either by expanding Nymphoides to include all of Villarsia and Liparophyllum, or by subdividing Villarsia among the three clades that resolve in phylogenetic analyses (Fig. 1). Under the former scenario, the defining morphological features of Nymphoides, namely floating leaves that support a lax inflorescence, would no longer be diagnostic for the genus. In addition, the inclusion of morphologically diverse species under Nymphoides could precipitate a concomitant condensation of Menyanthes and Nephrophyllidium into a single genus so that Menyanthaceae genera would remain equivalently diverse. Alternatively, the latter scenario of subdividing Villarsia would preserve the distinctness of Nymphoides as well as provide unifying morphological traits for the separate Villarsia clades. Under neither scenario would the genus name Villarsia apply to any taxon in Australia, because the type species $V$. capensis belongs to the isolated South African clade (Fig. 1). In our opinion, optimal clarity would be achieved by retaining Nymphoides as currently circumscribed (except for $N$. exigua), while subdividing Villarsia among the clades that were identified by the molecular and morphological data analyses.

Here we revise the nomenclature for species that formerly belonged to Villarsia. The genus name remains associated with $V$. capensis and the other two South African species, V. goldblattiana and $V$. manningiana Ornduff. For the morphologically diverse group that includes Liparophyllum gunnii, Nymphoides exigua, and several Villarsia species, the genus Liparophyllum is expanded to include all species resolving within the clade. Lastly, we establish a new genus to accommodate the third group of Villarsia species, which is separated from other taxa in the phylogenetic analysis by a welldefined, strongly supported branch (Fig. 1; Tippery et al., 2008). The appropriate taxonomic combinations, including emended descriptions of the genera Liparophyllum and Villarsia, are provided below.

\section{Taxonomic Treatment}

I. Liparophyllum Hooker f., London J. Bot. 6: 472. 1847. TYPE: Liparophyllum gunnii Hooker f., London J. Bot. 6: 473. 1847.

Aquatic or wetland annual or perennial herbs. Radical leaves erect, with sheathing bases; sessile and linear (Liparophyllum gunnii) or petiolate with ovate or ellipsoid laminae, margins entire to crenatedentate. Inflorescence paniculate; flowers 1 to 3 per node or congested into dense, sessile or subsessile capitula (L. capitatum (Nees ex Lehmann) Tippery \& Les, L. congestiflorum (F. Mueller) Tippery \& Les), or the whole inflorescence consisting of 1 to 5 flowers (L. exiguum (F. Mueller) Tippery \& Les, L. gunnii, L. violifolium (F. Mueller) Tippery \& Les). Calyx persistent, divided into 5 lobes; corolla yellow or white, gamopetalous, 5-lobed, rotate, throat fimbriate, margins entire or serrulate; stamens 5 , alternate with corolla lobes, inserted on the corolla tube at the junction of the lobes; anthers 2-celled, sagittate, introrse; ovary unilocular with 2 parietal placentae; base surrounded by 5 glands (absent in $L$. gunnii); style solitary with 2 stigmas; ovules 5 to 10 per placenta. Capsule dehiscent into 4 valves, adnate to calyx at the base only (L. gunnii, L. lasiospermum (F. Mueller) Tippery \& Les) or for more than $1 / 4$ of length, of equal length or longer than the calyx; seeds $0.7-3 \mathrm{~mm}$ diam., orbicular or ellipsoid, smooth or sparsely covered with trichomes $(<1$ trichome per 
epidermal cell; L. exaltatum (Solander ex Sims) Tippery \& Les, L. lasiospermum), hilum terminal (angle between major axis and hilum with vertex at seed center $<30^{\circ}$; angle approaches $30^{\circ}$ in $L$. exaltatum and $L$. latifolium), caruncle present ( $L$. congestiflorum, L. exaltatum, L. latifolium, L. violifolium (Bentham) Tippery \& Les) or lacking.

1. Liparophyllum capitatum (Nees ex Lehmann) Tippery \& Les, comb. nov. Basionym: Villarsia capitata Nees ex Lehmann, Pl. Preiss. 1: 365. 1845. Limnanthemum capitatum (Nees ex Lehmann) F. Mueller, Fragm. 9: 40. 1858. Renealmia capitata (Nees ex Lehmann) Kuntze, Revis. Gen. Pl. 430. 1891. TYPE: Australia. Western Australia: "In paludosis ad flumen Canning, Perth," Nov. 1841, L. Preiss 1956 (holotype, LD; isotypes, B, G [2 sheets], GOET, L [3 sheets], M not seen, MEL [2 sheets], NSW, S, STR).

Villarsia involucrata Hooker, Icon. Pl. viii. 725. 1845. TYPE: Australia. Western Australia: Swan River, J. Drummond 7 (holotype, K; isotype, MEL).

Typification. Duplicates of Preiss 1956 are lodged in herbaria in Europe and Australia, although few of these bear more than cursory label information. Preiss specimens that were owned by Lehmann reside at LD (Stafleu \& Cowan, 1983); indeed, the label of their Preiss 1956 specimen bears locality information, apparently written by Preiss, matching the protologue: "In paludosis ad fl. Canning (Perth), Novbr. 41," with an additional note: "Flor. flavi." The species name appears above, clearly written by Nees. Although there are numerous duplicates of Preiss 1956, the provenance of the LD specimen and its annotation by both Preiss and Nees leave little doubt that it should be regarded as the holotype.

2. Liparophyllum congestiflorum (F. Mueller) Tippery \& Les, comb. nov. Basionym: Villarsia congestiflora F. Mueller, Fragm. 6: 141. 1868. Limnanthemum congestiflorum (F. Mueller) F. Mueller, Syst. Census Austral. Pl. 90. 1882. Renealmia congestiflora (F. Mueller) Kuntze, Revis. Gen. Pl. 430. 1891. TYPE: Australia. Western Australia: Murchison River, s.d., A. F. Oldfield s.n. (lectotype, designated here, MEL).

Typification. In the original description of Villarsia congestiflora, Mueller (1868) designated two specimens, both collected by Oldfield: "Ad fluvios Swan-River et Murchison-River. Oldf." Three Oldfield specimens annotated by Mueller reside at MEL. Two of these (MEL 872 and 873) give only the locality "Near Perth" written by Oldfield, with another label on which Mueller wrote "Swan River." The third specimen (MEL 874), which we have selected as the lectotype, is the only one whose original label (written by Oldfield) matches the published text, and furthermore it represents the most morphologically complete specimen of the three.

3. Liparophyllum exaltatum (Solander ex Sims) Tippery \& Les, comb. nov. Basionym: Menyanthes exaltata Solander ex Sims, Bot. Mag. 26: 1029. 1807. Limnanthemum exaltatum (Solander ex Sims) F. Mueller, Fragm. 9: 165. 1875. Renealmia exaltata (Solander ex Sims) Kuntze, Revis. Gen. Pl. 430. 1891. TYPE: Australia. New South Wales: 28 Apr.-5 May 1770, J. Banks \& D. C. Solander s.n. (lectotype, designated by Aston, 1969: 44, BM; isotype, NSW not seen).

4. Liparophyllum exiguum (F. Mueller) Tippery \& Les, comb. nov. Basionym: Limnanthemum exiguum F. Mueller, Fragm. 1: 40. 1858. Villarsia exigua (F. Mueller) Hooker f., Bot. Antaret. Voy., Vol. 3, Fl. Tasman. 2: 368. 1859. Nymphoides exigua (F. Mueller) Kuntze, Revis. Gen. Pl. 430. 1891. TYPE: Australia. Tasmania: "Wet muddy places in brackish water, South Port," s.d., A. F. Oldfield s.n. (holotype, K).

5. Liparophyllum lasiospermum (F. Mueller) Tippery \& Les, comb. nov. Basionym: Villarsia lasiosperma F. Mueller, Fragm. 6: 137. 1868. Limnanthemum lasiospermum (F. Mueller) F. Mueller, Fragm. 9: 165. 1875. Renealmia lasiosperma (F. Mueller) Kuntze, Revis. Gen. Pl. 430. 1891. TYPE: Australia. Western Australia: Swamps at King George Sound, Albany, Oct. 1867, F. Mueller s.n. (lectotype, designated here, MEL).

Typification. Mueller (1868) listed several of his own collections in the description of Villarsia lasiosperma: "In paludibus aqua pura repletis prope urbem Albany, ad bases montium Willyung et montes Porongorup versus. F.M." Three specimens at MEL were interpreted by Aston (1969) to represent syntypes, although curiously none of their labels matches the published text exactly: "Forest swamps north of Albany, Oct. 1867," with an apparently later label "Swamps at King George's Sound, Oct. 67" (MEL 875); "Swamps in the rear of Mt. Melville, Oct. 67 ," two packets apparently containing seeds, with a later label "Swamps at King George's Sound (fresh water), Oct. 67" (MEL 16493); "Heath swamps north of Albany, Oct. 1867," with the same text reproduced on a later label (MEL 16494). We have selected the first of these (MEL 875) to be the lectotype, because it is the most morphologically complete specimen and 
its locality description most closely matches the text of the original publication.

6. Liparophyllum latifolium (Bentham) Tippery \& Les, comb. nov. Basionym: Villarsia latifolia Bentham, Enum. Pl. (Endlicher) 81. 1837. Limnanthemum latifolium (Bentham) F. Mueller, Fragm. 9: 164. 1875. Renealmia latifolia (Bentham) Kuntze, Revis. Gen. Pl. 430. 1891. TYPE: Australia. Western Australia: "King George's Sound," s.d., C. Hügel s.n. (holotype, W).

7. Liparophyllum violifolium (F. Mueller) Tippery \& Les, comb. nov. Basionym: Villarsia violifolia F. Mueller, Fragm. 6: 138. 1868. Limnanthemum violifolium (F. Mueller) F. Mueller, Syst. Census Austral. Pl. 90. 1882. Renealmia violifolia (F. Mueller) Kuntze, Revis. Gen. Pl. 430. 1891. TYPE: Australia. Western Australia: Don River, s.d., T. C. Maxwell s.n. (lectotype, designated here, MEL).

Typification. Mueller (1868) listed several localities and collectors in the original description of Villarsia violifolia: "Ad fluvios Tweed et Don's River; Oldf. Maxw. Prope urbem Hamden, Clarke." Three specimens at MEL, clarified by Aston (1969), conform to the description: "S. W. Austr." collected by Clarke (label in Mueller's hand; MEL 16489); "Plts. matted, fl. yellow, Tweed R. W. Aust." collected by Oldfield (MEL 16490); "Don River, S. W. Aust." collected by Maxwell (labels written by Mueller; MEL 16491 and 16492). Of these, the most complete specimen is the collection by Maxwell, specifically MEL 16491, which we designate as the lectotype.

II. Ornduffia Tippery \& Les, gen. nov. TYPE: Villarsia reniformis R. Brown, Prodr. Fl. Nov. Holland. 437. $1810 \equiv$ Ornduffia reniformis (R. Brown) Tippery \& Les.

Genus foliis simplicibus, inflorescentia diffusa paniculataque, lobo corollino quoque alam medianam carenti, capsula fundo solum ad calycem adnata, seminibus non carunculatis Villarsiae Ventenat simile, sed ab eo marginibus loborum corollinorum integris serrulatisve, ovulis ad quamque placentam plus quam 10 , seminibus ellipticis hilo subterminali differt.

Aquatic or wetland perennial herbs. Radical leaves erect or floating, petiolate, with sheathing bases; laminae simple, ovate or ellipsoid, margins entire to crenate-dentate. Inflorescence paniculate; flowers 1 to 3 per node. Calyx persistent, divided into 5 lobes; corolla yellow or white, gamopetalous, 5 -lobed, rotate, throat fimbriate, margins entire or serrulate; stamens 5 , alternate with corolla lobes, inserted on the corolla tube at the junction of the lobes; anthers 2-celled, sagittate, introrse; ovary unilocular with 2 parietal placentae; base surrounded by 5 glands; style solitary with 2 stigmas; ovules 11 or more per placenta. Capsule dehiscent into 4 valves, adnate to calyx only at the base; seeds $0.5-1.9 \mathrm{~mm}$ diam., ellipsoid, smooth or densely covered with trichomes (one per epidermal cell; O. albiflora (F. Mueller) Tippery \& Les, O. calthifolia (F. Mueller) Tippery \& Les, O. marchantii (Ornduff) Tippery \& Les, O. umbricola var. beaugleholei (Aston) Tippery \& Les), hilum subterminal (angle between major axis and hilum with vertex at seed center $>30^{\circ}$ ), without a conspicuous caruncle.

Etymology. We have chosen the generic name Ornduffia to honor the late Robert Ornduff (19322000), who contributed immensely to the study of reproductive system ecology and evolution in Menyanthaceae, and Villarsia in particular.

1. Ornduffia albiflora (F. Mueller) Tippery \& Les, comb. nov. Basionym: Villarsia albiflora $\mathrm{F}$. Mueller, Fragm. 2: 21. 1860. Limnanthemum albiflorum (F. Mueller) F. Mueller, Syst. Census Austral. Pl. 90. 1882. Renealmia albiflora (F. Mueller) Kuntze, Revis. Gen. Pl. 430. 1891. TYPE: Australia. Western Australia: Perth, s.d., A. F. Oldfield s.n. (lectotype, designated here, MEL).

Typification. Mueller (1860) indicated two collections in the description of Villarsia albiflora: "In stagnis propre oppida Perth et Hampden. Clarke et Oldfield." Aston (1969) located two corresponding Oldfield specimens at MEL: "Fl. white, Hampden, W. A." (MEL 16430) and "Perth, W. Aust." (MEL 16447). We designate the latter specimen (MEL 16447), which has more leaves and flowers, as the lectotype.

2. Ornduffia calthifolia (F. Mueller) Tippery \& Les, comb. nov. Basionym: Villarsia calthifolia $\mathrm{F}$. Mueller, Fragm. 6: 140. 1868. Limnanthemum calthifolium (F. Mueller) F. Mueller, Fragm. 9: 164. 1875. Renealmia calthifolia (F. Mueller) Kuntze, Revis. Gen. Pl. 430. 1891. TYPE: Australia. Western Australia: Porongorup, Oct. 1867, F. Mueller s.n. (lectotype, designated here, MEL).

Typification. The original description of Villarsia calthifolia (Mueller, 1868) listed the locality "In rivulis et in summitatibus rupestribus montium Porongorup. F. M." Aston (1969) identified three Mueller specimens that she considered syntypes: "Porongorup" (MEL 16480); "Summit of the Porongorup. Cor. yellow. Oct. 67" (MEL 16481); and "Porongorup" (NSW 90574). None of the specimens 
represents an entire plant, but the most complete combination of leaf and inflorescence occurs on one of the Melbourne sheets (MEL 16481), which we designate as the lectotype.

3. Ornduffia marehantii (Ornduff) Tippery \& Les, comb. nov. Basionym: Villarsia marchantii Ornduff, Syst. Bot. 15: 216-220. 1990. TYPE: Australia. Western Australia: Wet soil in deep shade of Trymalium thicket, below Wansbrough Walk on N side of Porongorup Range, elevation 450 m, 15 Nov. 1983, R. Ornduff 9323 (holotype, PERTH).

4. Ornduffia parnassifolia (Labillardière) Tippery \& Les, comb. nov. Basionym: Swertia parnassifolia Labillardière, Nov. Holl. Pl. 1: 72, t. 97. 1805. Villarsia parnassifolia (Labillardière) R. Brown, Prodr. Fl. Nov. Holland. 457. 1810, as "V. parnassiifolia." Limnanthemum parnassifolium (Labillardière) F. Mueller, Fragm. 9: 165. 1875. Renealmia parnassifolia (Labillardière) Kuntze, Revis. Gen. Pl. 430. 1891. TYPE: Australia. Western Australia: In terra VanLeeuwin, s.d., J. J. H. Labillardière s.n. (lectotype, designated by Aston, 1969: 37, FI; isotypes, BM, MEL, NSW).

5. Ornduffia reniformis (R. Brown) Tippery \& Les, comb. nov. Basionym: Villarsia reniformis $\mathrm{R}$. Brown, Prodr. Fl. Nov. Holland. 457. 1810. TYPE: Australia. Tasmania: Port Dalrymple, s.d., W. Paterson s.n. (lectotype, designated by Aston, 1969: 50, BM).

6. Ornduffia submersa (Aston) Tippery \& Les, comb. nov. Basionym: Villarsia submersa Aston, Muelleria 2: 19. 1969. TYPE: Australia. Western Australia: Boyanup, 9 Sep. 1953, R. D. Royce 3778 (holotype, PERTH; isotype, MEL).

7. Ornduffia umbricola (Aston) Tippery \& Les, comb. nov. Basionym: Villarsia umbricola Aston, Muelleria 2: 53. 1969. TYPE: Australia. South Australia: ca. 4 mi. direct line ESE of Myponga, betw. Myponga \& Hindmarsh Valley, 18 Dec. 1966, H. I. Aston 1531 (holotype, MEL; isotypes, AD not seen, $\mathrm{K}$ not seen, NSW).

8. Ornduffia umbricola var. beaugleholei (Aston) Tippery \& Les, comb. nov. Basionym: Villarsia umbricola var. beaugleholei Aston, Muelleria 2: 55. 1969. TYPE: Australia. Victoria: $1.3 \mathrm{mi}$. W of Dergholm, along the rd. to Penola, 15 Dec. 1965, H. I. Aston 1445 (holotype, MEL; isotypes, AD not seen, BM not seen, $\mathrm{K}$ not seen, MEL not seen, NSW, PERTH).
III. Villarsia Ventenat, Choix Pl. t. 9. 1803, nom. cons. TYPE: Villarsia ovata (L. f.) Ventenat, Choix Pl. t. 9. 1803, typ. cons., $\equiv$ Menyanthes ovata L. f., Suppl. Pl. 133. 1781, = V. capensis (Houttuyn) Merrill, J. Arnold Arbor. 19: 360. 1938. Renealmia capensis Houttuyn, Handl. Pl.Kruidk. 8: 335. 1777.

Aquatic or wetland perennial herbs. Radical leaves erect, with sheathing bases; petiolate with ovate or ellipsoid laminae, margins entire to crenate-dentate. Inflorescence paniculate; flowers 1 to 3 per node. Calyx persistent, divided into 5 lobes; corolla yellow, gamopetalous, 5-lobed, rotate, throat fimbriate, margins deeply fimbriate; stamens 5 , alternate with corolla lobes, inserted on the corolla tube at the junction of the lobes; anthers 2-celled, sagittate, introrse; ovary unilocular with 2 parietal placentae; base surrounded by 5 glands; style solitary with 2 stigmas; ovules 1 to 4 per placenta. Capsule dehiscent into 4 valves, adnate to calyx only at the base; of equal length or shorter than the calyx; seeds 1.5-2.5 mm diam., orbicular, smooth or with bulliform protuberances, hilum terminal (angle between major axis and hilum with vertex at seed center $>30^{\circ}$ ), without a conspicuous caruncle.

\section{Key to Genera of Menyanthaceae Worldwide}

1a. Leaves trifoliate; inflorescence an erect raceme with $>10$ flowers. . . . . . . . . Menyanthes

1b. Leaves simple; inflorescence lax, or if erect, then capitate, paniculate, or consisting of $<5$ flowers. . . 2

2a. Leaves erect, their margins distinctly crenate; pollen grains subprolate to prolate; seeds with distinct, narrowly elongate epidermal cells, their surface smooth............ Nephrophyllidium

2b. Leaves floating, or if erect then margins entire, dentate, or indistinctly crenate; pollen grains peroblate to suboblate; seeds with indistinct or orbicular epidermal cells, their surface smooth, roughened, tuberculate, or possessing trichomes . . . 3

3a. Plants submersed with floating leaves (emergent in mudflat forms or when crowded); inflorescence lax, the flowers in pairs or umbellate, supported by 1 or more floating leaves, or erect and paniculate with $>10$ flowers occurring in pairs ...... Nymphoides

3 b. Plants submersed (O. submersa) or emergent, with erect and/or floating leaves; inflorescence erect or lax; if erect, then either capitate, paniculate with flowers arising singly (rarely paired), or consisting of $\leq 5$ flowers; if lax, then never supported by a floating leaf $(O$. submersa) . . . . . . . . 4

4a. Corolla lobe margins fimbriate; each placenta with 1 to 4 ovules; seeds orbicular, $>1.5 \mathrm{~mm}$ diam... . Villarsia

4b. Corolla lobe margins entire or serrulate; each placenta with $\geq 5$ ovules; seeds ellipsoid, or $<1.4 \mathrm{~mm}$ diam. if orbicular .......... 5

5a. Each placenta with 5 to 10 ovules; inflorescence capitate, paniculate, or reduced to $\leq 5$ flowers; seeds lacking trichomes on some or all epidermal cells; if trichomes absent, then either margins of 
epidermal cells inconspicuous (under $100 \times$ magnification) or seed caruncle present. . . Liparophyllum

5 b. Each placenta with $\geq 11$ ovules; inflorescence always paniculate with $>10$ flowers; seeds bearing a trichome on each epidermal cell or, if trichomes absent, then margins of epidermal cells conspicuous; seed caruncle absent ...... Ornduffia

Acknowledgments. The authors are indebted to the directors and staff of the following herbaria for providing access to specimens and type material: A, B, BM, BRI, CAL, CONN, FI, G, GH, GOET, K, L, LD, MEL, MO, NSW, NT, NY, PERTH, PRE, S, STR, UC, US, W, in particular Arne Anderberg (S), Peter Audiffred (L), Frances Crawford (K), Andrew Doran (UC), Mia Ehn (S), Holly Forbes (UC), Patrik Frödén (LD), Laurent Gautier (G), Jochen Heinrichs (GOET), Michel Hoff (STR), Nimal Karunajeewa (MEL), Karina Knight (PERTH), Egildo Luccioli (FI), Pina Milne (MEL), John Strother (UC), Christine Taylor (BM), Kevin Thiele (PERTH), Roy Vickery (BM), Ernst Vitek (W), Robert Vogt (B), and Håkan Wittzell (LD). We also thank Don Padgett for his contributions to understanding phylogenetic relationships in Menyanthaceae, Tony Rebelo for collecting live material, Victoria C. Hollowell for helpful comments on the manuscript, and Helen Aston and Surrey Jacobs for their valuable insights on the Australian taxa.

\section{Literature Cited}

Aston, H. I. 1969. The genus Villarsia (Menyanthaceae) in Australia. Muelleria 2: 3-63.

— 1973. Aquatic Plants of Australia. Melbourne University Press, Carlton, Victoria.

Bentham, G. \& F. von Mueller. 1869. Gentianaceae. Pp. 369-382 in Flora Australiensis, Vol. 4. L. Reeve \& Co., London.

— \& J. D. Hooker. 1876. Genera Plantarum, Vol. 2. L. Reeve \& Co., London.

Brown, R. 1810. Prodromus Florae Novae Hollandiae et Insulae Van-Diemen, Vol. 1. R. Taylor et Socii, London.

Chuang, T. I. \& R. Ornduff. 1992. Seed morphology and systematics of Menyanthaceae. Amer. J. Bot. 79: 1396-1406.

Cook, C. D. K. 1996. Aquatic Plant Book. SPB Academic Publishers, New York.

Don, G. 1837. A General History of the Dichlamydeous Plants, Vol. 4. C. J. G. and F. Rivington, London.

Endlicher, S. F. L., G. Bentham, E. Fenzl, C. A. A. von Hügel \& H. W. Schott. 1837. Enumeratio Plantarum. F. Beck, Vienna.

Gmelin, S. G. 1769. Lychanthos volubilis et Limnanthemum peltatum, nova plantarum genera. Novi Comment. Acad. Sci. Imp. Petrop. 14: 525-530.

Grisebach, A. H. R. 1845. Tribus II. Menyantheae. Pp. 136-141 in A. P. de Candolle (editor), Prodromus Systematis Naturalis Regni Vegetabilis, Vol. 9. Treuttel et Würtz, Paris.

Hooker, J. D. 1847. Flora Tasmaniae Spicilegium. London J. Bot. 6: 461-479.

Kuntze, C. E. O. 1891. Revisio Generum Plantarum. A. Felix, Leipzig.
Labillardière, J. J. H. de. 1804-1805. Novae Hollandiae Plantarum Specimen, Vol. 1. Dominae Huzard, Paris.

Lehmann, J. G. C. 1845. Plantae Preissianae, Vol. 1. Sumptibus Meissneri, Hamburg.

Linnaeus, C. 1753. Species Plantarum, Vol. 1. L. Salvius, Stockholm.

Lundberg, J. \& K. Bremer. 2003. A phylogenetic study of the order Asterales using one morphological and three molecular data sets. Int. J. Pl. Sci. 164: 553-578.

Mueller, F. J. H. von. 1854. Definitions of rare or hitherto undescribed Australian plants, chiefly collected within the boundaries of the Colony of Victoria. Trans. Philos. Soc. Victoria 1: 5-24.

. 1858. Fragmenta Phytographiae Australiae..., Vol. 1. Auctoritate Gubern. Coloniae Victoriae, ex Officina Joannis Ferres, Melbourne.

- 1860. Fragmenta Phytographiae Australiae..., Vol. 2. Auctoritate Gubern. Coloniae Victoriae, ex Officina Joannis Ferres, Melbourne.

. 1865. Fragmenta Phytographiae Australiae..., Vol. 5. Auctoritate Gubern. Coloniae Victoriae, ex Officina Joannis Ferres, Melbourne.

- 1868. Fragmenta Phytographiae Australiae..., Vol. 6. Auctoritate Gubern. Coloniae Victoriae, ex Officina Joannis Ferres, Melbourne.

- 1875. Fragmenta Phytographiae Australiae..., Vol. 9. Auctoritate Gubern. Coloniae Victoriae, ex Officina Joannis Ferres, Melbourne.

Nilsson, S. 1973. Menyanthaceae Dum. Taxonomy by Robert Ornduff. World Pollen Spore Fl. 2: 1-20.

Olmstead, R. G., K.-J. Kim, R. K. Jansen \& S. J. Wagstaff. 2000. The phylogeny of the Asteridae sensu lato based on chloroplast $n d h \mathrm{~F}$ gene sequences. Molec. Phylogen. Evol. 16: 96-112.

Ornduff, R. 2001. A(nother) new species of Villarsia (Menyanthaceae) from South Africa. Novon 11: 437-439.

Séguier, J.-F. 1754. Plantae Veronenses..., Vol. 3. A. Andreonii, Verona.

Sims, J. 1807. Curtis's Botanical Magazine, Vol. 26. S. Couchman, London.

1810. Curtis's Botanical Magazine, Vol. 32. S. Couchman, London.

Soltis, D. E., P. S. Soltis, M. W. Chase, M. E. Mort, D. C. Albach, M. Zanis, V. Savolainen, W. H. Hahn, S. B. Hoot, M. F. Fay, M. Axtell, S. M. Swensen, L. M. Prince, W. J. Kress, K. C. Nixon \& J. S. Farris. 2000. Angiosperm phylogeny inferred from $18 \mathrm{~S} \mathrm{rDNA}, r b c \mathrm{~L}$, and $a t p \mathrm{~B}$ sequences. Bot. J. Linn. Soc. 133: 381-461.

Stafleu, F. A. \& R. S. Cowan. 1983. Taxonomic Literature 4 [TL-2]. Regnum Veg. 110. Bohn, Scheltema \& Holkema, Utrecht.

Takhtajan, A. 1986. Floristic Regions of the World. University of California Press, Berkeley.

Tippery, N. P. \& D. H. Les. 2008. Phylogenetic analysis of the internal transcribed spacer (ITS) region in Menyanthaceae using predicted secondary structure. Molec. Phylogen. Evol. 49: 526-537.

$\longrightarrow,-$ D. J. Padgett \& S. W. L. Jacobs. 2008. Generic circumscription in Menyanthaceae: A phylogenetic evaluation. Syst. Bot. 33: 598-612.

$\longrightarrow,-$, J. C. Regalado, Jr., L. V. Averyanov, N. L. Vu \& P. H. Raven. 2010. Transfer of Villarsia cambodiana to Nymphoides (Menyanthaceae). Syst. Bot. (in press).

Tournefort, J. P. 1700. Institutiones Rei Herbariae.... Typographia Regia, Paris.

Ventenat, É. P. 1803. Choix de Plantes.... Crapelet, Paris. 


\section{$2 \mathrm{BHL}$ Biodiversity Heritage Library}

Tippery, Nicholas P. and Les, Donald H. 2009. "A New Genus and New Combinations in Australian Villarsia (Menyanthaceae)." Novon a journal of botanical nomenclature from the Missouri Botanical Garden 19, 404-411.

View This Item Online: https://www.biodiversitylibrary.org/item/124658

Permalink: https://www.biodiversitylibrary.org/partpdf/121942

\section{Holding Institution}

Missouri Botanical Garden, Peter H. Raven Library

\section{Sponsored by}

Missouri Botanical Garden

\section{Copyright \& Reuse}

Copyright Status: Permission to digitize granted by rights holder Rights: https://www.biodiversitylibrary.org/permissions

This document was created from content at the Biodiversity Heritage Library, the world's largest open access digital library for biodiversity literature and archives. Visit BHL at https://www.biodiversitylibrary.org. 